\title{
Pengaruh Corporate Governance terhadap Profitabilitas Bank Umum Syariah (BUS) Indonesia Periode 2011-2016
}

\author{
Jielend Ariandhini \\ Program Studi Ekonomi Syariah, Fakultas Agama Islam \\ Universitas Muhammadiyah Malang \\ Email: jielend1995@gmail.com
}

\begin{abstract}
This study aims to determine the effect of Corporate Governance (CG) as measured by the composition of the board of commissioners, the composition of the board of directors, the composition of the audit committee and the composition of the syariah supervisory board on the profitability of sharia commercial banks as measured by Return On Assets (ROA). The Method of this research is quantitatif by using secondary data with documentation technique. The population used in this study is all sharia commercial banks, based on the financial statements of each bank. The observation period in this research is from 2011 to 2016. The sampling technique is done by purposive sampling method. There are 5 banks, namely Bank Muamalat, Bank Sharia Mandiri, Bank Negara Indonesia Sharia, Bank Rakyat Indonesia Sharia, Bank Central Asia Sharia. Data analysis technique used in this research is panel regression. The results showed that independent variables of board of commissioner and syariah supervisory board have no significant effect on financial performance measured by Return on Asset (ROA). The independent variable of the board of directors has a positive and significant impact on the financial performance measured using Return on Assets (ROA), and the audit committee independent variable has a negative and significant effect on the financial performance measured using Return on Assets (ROA).
\end{abstract}

Keywords: Corporate Governance, Islamic Bank, Syariah Supervisory, Return on Asset. 


\begin{abstract}
ABSTRAK
Penelitian ini bertujuan untuk mengetahui pengaruh Corporate Governance (CG) yang diukur dengan komposisi dewan komisaris, komposisi dewan direksi, komposisi komite audit dan komposisi dewan pengawas syariah terhadap profitabilitas bank umum syariah yang diukur dengan Return On Asset (ROA). Metode Penelitian ini adalah menggunakan data sekunder dengan teknik dokumentasi. Populasi yang digunakan dalam penelitian ini adalah seluruh bank umum syariah, berdasarkan laporan keuangan pada setiap bank tersebut. Periode pengamatan dalam penelitian ini adalah dari tahun 2011 sampai tahun 2016. Teknik pengambilan sampel dilakukan dengan metode purposive sampling. Total sebanyak 5 bank, yaitu Bank Muamalat, Bank Mandiri Syariah, Bank Negara Indonesia Syariah, Bank Rakyat Indonesia Syariah, Bank Central Asia Syariah. Teknik analisis data yang digunakan dalam penelitian ini adalah regresi panel. Hasil penelitian menunjukkan bahwa variabel independen dewan komisaris dan dewan pengawas syariah tidak berpengaruh signifkan terhadap kinerja keuangan yang diukur menggunakan Return On Asset (ROA). Variabel independen dewan direksi berpengaruh positif dan signifikan terhadap kinerja keuangan yang diukur menggunakan Return On Asset (ROA), dan variabel independen komite audit berpengaruh negatif dan signifikan terhadap kinerja keuangan yang diukur menggunakan Return On Asset (ROA).
\end{abstract}

Kata Kunci: Corporate Governance, Komposisi Dewan Komisaris, Komposisi Dewan Direksi, Komposisi Komite Audit, Komposisi Dewan Pengawas Syariah, Return On Asset.

\title{
1. Pendahuluan
}

Perkembangan perbankan syariah pada era reformasi ditandai dengan sistem perbankan Indonesia mengakui keberadaan bank syariah dan memberikan kesempatan untuk beroperasi, hal ini dilihat dari disetujuinya UU No.10 Tahun 1998. Undang-undang inilah secara tegas membedakan bank berdasarkan prinsip konvensional serta bank berdasarkan prinsip syariah (Maradita, 2014: 192). Pendirian bank syariah telah mendorong sektor industri keuangan syariah lainnya seperti lembaga akademik, rumah sakit dan komunitas masyarakat yang peduli dengan perkembangan industri keuangan syariah. Dukungan pemerintah semakin terlihat yaitu telah diterbitkannya UU No.21 Tahun 2008 tentang perbankan syariah. Pemerintah juga mendirikan Komite Nasional Keuangan Syariah (KNKS) pada tahun 2015 langsung dipimpin oleh Presiden Joko Widodo, ini menunjukkan pemihakan yang jelas pemerintah terhadap bank syariah. KNKS ini diharapkan 
menjadi pilar penting tumbuhnya industri keuangan syariah pada masa mendatang.

Bank syariah telah 26 tahun beroperasi, semakin bertambah di pasar keuangan. Jumlah bank syariah saat ini tercatat 196 unit, terdiri atas 13 Bank Umum Syariah (BUS), 23 Unit Usaha Syariah (UUS), dan 160 Bank Perkreditan Rakyat (BPRS). Perbedaan ketiganya yaitu, BUS adalah bank syariah yang dalam kegiatannya memberikan jasa melalui lalu lintas pembayaran, UUS adalah unit kerja dari kantor pusat bank umum konvensional yang sebagai kantor induk dari kantor atau unit yang melaksanakan kegiatan usaha berdasarkan prinsip syariah, dan BPRS yaitu dalam kegiatnnya tidak memberikan jasa dalam lalu lintas pembayaran (https://www.syariahbank.com), sehingga digunakan BUS karena sudah melakukan spin-off dari bank konvensional (http://aceh.tribunnews.com).

Indonesia pernah mengalami krisis keuangan pada tahun 1997, merusak perekonomian Indonesia khususnya dunia perbankan menyebabkan penurunan kinerja perbakan nasional, berbagai penelitian menyebutkan bahwa krisis ekonomi yang hebat yang melanda Indonesia terjadi karena buruknya penerapan Corporate Governance di Indonesia. Akar penyebab timbulnya krisis ekonomi di Indonesia dan juga di berbagai negara ASIA salah satunya adalah buruknya pelaksanaan Corporate Governance hampir semua perusahaan yang ada, baik perusahaan yang dimiliki pemerintah (BUMN) maupun yang dimiliki pihak swasta. Konferensi pers ISCA (Indonesian Corporate Secretary Association) memberikan pernyataan kenapa sampai saat ini penerapan Corporate Governance (CG) belum maksimal, karena lembaga-lembaga yang terkait belum sepenuhnya mendukung terciptanya tata kelola Indonesia yang lebih baik. ISCA adalah salah satu organisasi yang peeduli terhadap terciptanya tata kelola Indonesia yang lebih baik (http://bisnisupdate.com).

Data Otoritas Jasa Keuangan (OJK) menunjukkan bahwa pertumbuhan aset perbankan syariah pada akhir 2017 mengalami kenaikan sebesar $24.4 \%$ menjadi Rp 379.7 triliun dibandingkan dengan periode yang sama pada tahun 2016 (https://www.erhaje88.com). Tingkat kinerja keuangan perbankan dilakukan untuk menganalisis rasio keuangan berpengaruh pada kesehatan perbankan, dilihat tingkat profitabilitas seberapa besar yang dihasilkan perusahaan (Sholihin, 2010: 556). Rasio yang digunakan dalam mengukur rasio profitabilitas yaitu Return On Asset (ROA), karena ROA adalah rasio yang menggambarkan kemampuan atau produktivitas bank dalam mengelola dana yang diinvestasikan seluruh aktivanya untuk menghasilkan keuntungan (Muhammad, 2015: 254).

Corporate Governance (CG) dapat mempengaruhi kinerja perbankan yaitu terungkap pada wawancara dengan para direktur perbankan, menyatakan bahwa perbankan yang menjunjung nilai disiplin pasar dan tata kelola perusahaan yang baik akan lebih sehat, lebih dipercaya serta memiliki kemampuan untuk beradaptasi dalam berbagai masalah (http://www.beritasatu.com). 
Peranan pemerintah dalam peningkatan Corporate Governance khususnya pada perbankan syariah dilakukan dengan menetapkan kebijakan melalui Bank Indonesia yang tercantum di Peraturan Bank Indonesia (PBI) Nomor 8/4/PBI/2006 tentang CG bagi bank umum sudah tidak berlaku lagi pada perbankan syariah, telah diperbarui yaitu Peraturan Bank Indonesia Nomor 11/33/PBI/2009 tentang CG bagi bank umum syariah dan unit usaha syariah. Pelaksanaan CG diperlukan untuk membangun kepercayaan masyarakat dan dunia Internasional sebagai syarat mutlak bagi dunia perbankan untuk berkembang baik dan sehat (Peraturan Bank Indonesia (PBI) No.11/33/PBI/2009). Corporate Governance (CG) adalah salah satu hal yang penting dilakukan oleh perusahaan sebagai suatu tanggung jawab kepada stakeholder. CG juga menetapkan hubungan pemegang saham, pengurus, pihak kreditur, pemerintah, karyawan, pemegang saham internal dan eksternal atau sistem yang mengarahkan dan mengendalikan perusahaan juga sebagai sarana untuk menentukan teknik monitoring kinerja (mengawasi kinerja) (Sriwedari, 2012). Kelima sudut pandang tersebut penelitian ini fokus pada pengurus atau pengelola CG. Selain itu, posisi dewan direksi sebagai pimpinan perusahaan bertugas dan bertanggungjawab dalam mengelola perusahaan, dewan komisaris memastikan bahwa manajemen telah bekerja dengan baik. Komite audit dipercayai dalam proses penyusunan laporan keuangan dan menjaga terciptanya sistem pengawasan perusahaan serta terlaksananya CG. Dewan pengawas syariah mempunyai tugas utama untuk mengawasi operasional bank syariah sehari-hari agar sesuai dengan petunjuk dan ketentuan-ketentuan syariat Islam (Sunarwan, 2015: 5-6).

Penelitian ini bertujuan untuk menjelaskan sejauh mana tingkat keberhasilan perbankan syariah dalam menerapkan Corporate Governance serta pengaruhnya terhadap kinerja keuangan Bank Umum Syariah (BUS) Periode 2011-2016.

\section{Tinjauan Pustaka}

Sutedi, (2012); Erfiza (2014); Adestian (2015), menyatakan bahwa komposisi anggota dewan komisaris yang banyak maka pengawasan terhadap dewan direksi menjadi jauh lebih baik, nasihat dan masukan untuk dewan direksi pun menjadi lebih banyak, sehingga dapat meningkatkan kinerja perbankan. Sementara menurut Addiyah (2014), menyatakan bahwa kebijakan dewan direksi dapat mempengaruhi keuangan BUS secara signifikan dan memiliki dampak terhadap anggaran, sumber daya manusia serta struktur organisasi (Usman, 2012: 273). Hal senada juga dinyatakan oleh Kartika (2014) dan Adestian (2015). Sementara Kartika dan Erfina (2014) menyatakan baha Komposisi Dewan Pengawas Syariah (DPS) tidak berpengaruh terhadap profitabilitas BUS yang diukur menggunakan ROA. Artinya setiap peningkatan atau penurunan DPS tidak akan berpengaruh terhadap ROA pada BUS. 


\subsection{Bank Syariah}

Lembaga keuangan atau perbankan yang memberi pembiayaan dan jasa-jasa lainnya dalam lalu lintas pembayaran dan peredaran uang serta pengoperasiannya didasarkan pada prinsip-prinsip syariah yakni mengacu pada ketentuan Al-Quran dan Al-Hadits dan juga aktivitas meninggalkan riba dan tidak mengandalkan bunga (Laksmana, 2009: 10). Dalam konteks corporate governance, perbedaan antara Bank syariah dan bank konvensional adalah keberadaan Dewan Pengawas Syariah (DPS) yang bersifat independen dan kedudukannya sejajar dengan Dewan Komisaris. Tugas utama DPS adalah melakukan pengawasan pada bank syariah yang mengacu fatwa Dewan Syariah Nasional (DSN) serta norma-norma syariah menyangkut operasionalisasi bank, produk bank islam dan moral manajemen.

\subsection{Corporate Governance (CG)}

Corporate Governance (CG) atau tata kelola perusahaan merupakan definisi teknis dalam praktik ekonomi yang telah menjadi bahasa pemerintahan. Kalimat Corporate Governance ini dikenalkan di publik Indonesia ketika tahun 1997-an perusahaan-perusahaan besar di Indonesia ambruk, yang disebabkan tidak patuhnya manajemen perusahaan terhadap prinsip-prinsip CG (Laksmana, 2009: 10).

Dewan komisaris adalah organ yang bertugas melakukan pengawasan secara umum atau khusus sesuai dengan anggaran dasar serta memberi nasihat kepada direksi sebagaimana dimaksud dalam Undang-Undang Nomor 40 Tahun 2007 tentang Perseroan Terbatas (Abdullah, 2010: 131). Sementara direksi bertanggung jawab penuh atas pelaksanaan pengelolaan bank umum syariah berdasarkan prinsip kehati-hatian dan prinsip syariah serta berkewajiban untuk mengelola bank umum syariah. Menurut Effendi, komite audit mempunyai fungsi membantu dewan komisaris dalam rangka mendukung efektivitas pelaksanaan tugas dan tanggung jawabnya. Pelaksanaan fungsi pengendalian seperti audit internal, kepatuhan, dan manajemen risiko antara lain dimaksudkan untuk membantu tugas pengendalian bank umum syariah (Effendi, 2016: 63).

Corporate Governance (CG) dalam pendekatan Islam, harus sungguhsungguh mampu berbasis orientasi nilai dan prinsip kejujuran dan keadilan terhadap semua pemangku kepentingan, dari sisi fungsi obyektifnya CG islami harus mengupayakan untuk kepentingan umum atau kemaslahatan umat atau disebut sebagai maqhashid al-syariah mencakup lima prinsip dasar: memelihara agama, kehidupan, akal, keturunan dan harta benda (Abdullah, 2010: 57).

\section{Metode Penelitian}

Objek penelitian ini mengenai pengaruh corporate governance terhadap profitabilitas bank umum syariah di Indonesia periode 2011-2016. Jenis penelitian dalam penelitian ini adalah deskriptif kuantitatif. Populasi yang digunakan dalam penelitian ini adalah seluruh bank umum syariah yang terdapat di Indonesia pada 
tahun 2011-2016. Pemilihan sampel dalam penelitian ini dilakukan dengan teknik purposive sampling. Purposive sampling adalah teknik penentuan sampel dengan pertimbangan tertentu. Penelitian ini menggunakan data sekunder. Teknik ini menggunakan teknik dokumentasi yaitu teknik untuk memperoleh data dengan cara mengumpulkan, mempelajari dan mengolah data. Teknik analisis data penelitian ini adalah data panel dari tahun 2011-2016 serta perbandingannya antar bank. Data panel adalah data yang mempunyai dua dimensi yaitu individu (crosssection) dan waktu (time series), dimana setiap unit cross-section (individu) diulang dalam beberapa periode waktu.

\section{Pembahasan}

4.1. Pengaruh Komposisi Dewan Komisaris terhadap Profitabilitas BUS

Berdasarkan hasil pengujian data, bahwa komposisi dewan komisaris berpengaruh positif dan signifikan terhadap profitabilitas BUS yang diukur menggunakan ROA. Artinya setiap peningkatan atau penurunan dewan komisaris akan berpengaruh terhadap ROA pada BUS, dewan komisaris memegang peranan penting dalam implementasi CG, serta merupakan inti dari corporate governance yang bertugas untuk menjamin pelaksanaan strategi, mengawasi manajemen dalam mengelola bank serta mewajibkan terlaksananya akuntanbilitas.

Tabel 1.1

Nilai Hasil Uji F

\begin{tabular}{llll}
\hline \multicolumn{4}{c}{ Uji F } \\
\hline Variabel & F-Stat & Prob & Keputusan \\
\hline$(\mathrm{x} 1, \mathrm{x} 2, \mathrm{x} 3, \mathrm{x} 4)$ & 3.48915 & 0.021410 & Signifikan \\
\hline
\end{tabular}

Hal ini berarti bahwa Ha diterima dan $\mathrm{H}_{0}$ ditolak, berarti dapat disimpulkan bahwa variabel independen meliputi: komposisi dewan komisaris, komposisi dewan direksi, komposisi komite audit dan komposisi dewan pengawas syariah secara bersama-sama (simultan) berpengaruh signifikan terhadap profitabilitas bank umum syariah yang diukur dengan ROA.

Tabel 1.2

Outer Model Pengaruh Corporate Governance terhadap Profitabilitas Bank Umum Syariah (BUS)

\begin{tabular}{cccl}
\hline Variabel & t-stat & Prob & Keputusan \\
\hline $\begin{array}{c}\text { Dewan } \\
\text { Komisaris (x1) }\end{array}$ & 3.508825 & 0.0017 & Signifikan \\
\hline Direksi (x2) & 2.401776 & 0.0241 & Signifikan \\
\hline Komite & 2.570115 & 0.0165 & Signifikan \\
\hline
\end{tabular}




\begin{tabular}{cccc}
\hline Audit $(\mathrm{x} 3)$ & & & \\
\hline DPS $(\mathrm{X} 4)$ & 0.277192 & 0.7839 & Tidak Signifikan \\
\hline
\end{tabular}

Komposisi anggota dewan komisaris yang banyak maka pengawasan terhadap dewan direksi menjadi jauh lebih baik, nasihat dan masukan untuk dewan direksi pun menjadi lebih banyak, dengan demikian kinerja perbankan juga semakin meningkat (Adestian, 2015: 10). Hasil penelitian ini sesuai penelitian Erfiza (2014; Sutedi, 2012: 156).

Allah SWT menjadikan manusia sebagai khalifah di bumi yang diberi tugas untuk menjaga bumi beserta isinya dari segala bentuk kesusakan (QS. AlBaqarah[2]: 30). Pertanggung jawaban manusia tersebut tidak hanya kepada masyarakat atau pemangku kepentingan tetapi kepada Allah SWT sebagai pemilik bumi seisinya (Febriani, 2016: 11-12), disini dewan komisaris menjalankan prinsip akuntabilitas dan pertanggungjawaban, maka hal ini menyebabkan dewan komisaris berpengaruh terhadap profitabilitas, karena dewan komisaris menjaga bank syariah dan melakukan pengawasan optimal dan meningkatkan profitabilitas dengan cara yang dianjurkan Allah SWT.

\subsection{Pengaruh Komposisi Komite Audit terhadap Profitabilitas BUS}

Berdasarkan hasil pengujian data, bahwa komposisi komite audit berpengaruh positif dan signifikan terhadap profitabilitas BUS yang diukur menggunakan ROA. Artinya setiap peningkatan ukuran komite audit akan menurunkan nilai ROA pada BUS, begitupun sebaliknya. Komite audit mempunyai fungsi membantu dewan komisaris dalam rangka mendukung efektivitas pelaksanaan tugas dan tanggung jawabnya. Pelaksanaan fungsi pengendalian seperti audit internal, kepatuhan, dan manajemen risiko antara lain dimaksudkan untuk membantu tugas pengendalian oleh direksi bank umum syariah.

Komite audit dalam melaksanakan tugasnya untuk membantu dewan komisaris dalam fungsi pengendalian seperti audit internal, kepatuhan, dan manajemen risiko. Komite audit juga memegang peranan penting dalam mewujudkan CG karena merupakan penyelidik dewan komisaris dalam rangka mengawasi jalannya suatu bank (Effendi, 2016: 63). Semakin banyak jumlah komite audit dalam perusahaan, maka semakin baik fungsi pengawasan yang dilakukan.

Fungsi komite audit salah satunya adalah menjembatani antara pemegang saham dan dewan komisaris dengan kegiatan pengendalian. Komite audit pada umumnya memiliki akses langsung dengan setiap unsur pengendalian dalam perusahaan, apabila banyak masukan yang diberikan antara komite audit dengan pihak yang berkepentingan akan menghasilkan peningkatan terutama untuk aspek pengendalian, sehingga dapat meningkatkan profitabilitas (Effendi, 2016: 59). Berdasarkan penelitian Kartika (2014) komite-komite berpengaruh terhadap kinerja perbankan. Allah SWT memerintahkan manusia setiap transaksi harus ditulis untuk menghindari ketidakadilan dan menjunjung tinggi kejujuran, hal ini 
seuai prinsip keterbukaan, komite audit telah menjalankannya sungguh-sungguh, maka dari itu komite audit berpengaruh dan menyebabkan menaikkan profitabilitas (Nalim, 2009: 11).

\subsection{Pengaruh Komposisi DPS terhadap Profitabilitas BUS}

Berdasarkan hasil pengujian data, bahwa komposisi DPS tidak berpengaruh terhadap profitabilitas BUS yang diukur menggunakan ROA. Artinya setiap peningkatan atau penurunan DPS tidak akan berpengaruh terhadap ROA pada BUS. Hasil penelitian ini sesuai dengan penelitian Kartika (2014) dan Erfina (2014). Tugas utama DPS adalah melakukan pengawasan pada bank islam yang mengacu fatwa Dewan Syariah Nasional (DSN) serta norma-norma syariah menyangkut operasionalisasi bank, produk bank islam, moral manajemen dan bertanggung jawab sesuai prinsip-prinsip GCG untuk memberikan nasihat, sran terhadap organ lainnya agar sesuai dengan prinsip syariah.

Praktiknya, DPS tidak berpengaruh terhadap profitabilitas perbankan karena pengawasan DPS hanya mengenai apakah bank tersebut sudah sesuai dengan syariah, dan perbankan syariah sangat rentan terhadap kesalahan-kesalahan syar'i, hal ini membuktikan bahwa pengawasan DPS rendah (Abdullah, 2010: 53), sehingga menyebabkan DPS tidak mempengaruhi profitabilitas, ada sebuah hadis yang menyatakan.

\subsection{Pengaruh Komposisi Dewan Redaksi terhadap Profitabilitas BUS}

Berdasarkan hasil pengujian data, bahwa komposisi dewan direksi berpengaruh positif dan signifikan terhadap profitabilitas BUS yang diukur menggunakan ROA. Artinya setiap peningkatan ukuran dewan direksi akan meningkatkan nilai ROA pada BUS, begitu juga sebaliknya.

Dewan direksi bertanggung jawab penuh atas pelaksanaan pengelolaan bank umum syariah berdasarkan prinsip kehati-hatian dan pronsip syariah. Komposisi dewan direksi yang semakin tinggi maka dalam mengelola bank semakin baik dalam menjalankan tugasnya tersebut dan dapat meningkatkan profitabiliitas bank. Independensi dewan direksi akan mendorong adanya keterbukaan perusahaan terhadap semua pemangku kepentingan melalui peningkatan kinerja perusahaan dan pengananan atas risiko-risiko yang dihadapi (Indroes, 2011: 253). Dewan direksi dalam satu bank akan menentukan kebijakan yang diambil secara jangka panjang maupun jangka pendek, maka apabila banyak dewan direksi akan memudahkan untuk koordinasi dalam pengambilan keputusan. Kebijakan dewan direksi dapat mempengaruhi keuangan BUS secara signifikan dan memiliki dampak terhadap anggaran, sumber daya manusia serta struktur organisasi (Usman, 2012: 273). Hasil penelitian ini sesuai dengan penelitian Addiyah (2014), Kartika (2014) dan Adestian (2015). 


\section{Kesimpulan}

Kesimpulan pengaruh CG yang diukur melalui komposisi dewan komisaris, komposisi dewan direksi, komposisi komite audit, dan komposisi dewan pengawas syariah, sedangkan profitabilitas Bank Umum Syariah (BUS) diukur menggunakan ROA.Berdasarkan hasil analisis dan pembahasan yang telah dijelaskan pada bab sebelumnya, maka kesimpulan dari penelitian ini adalah sebagai berikut.

Variabel komposisi dewan komisaris terhadap ROA berpengaruh positif dan signifikan terhadap profitabilitas. Artinya setiap peningkatan atau penurunan dewan komisaris berpengaruh signifikan terhadap profitabilitas. Variabel komposisi komposisi dewan direksi berpengaruh positif dan signifikan terhadap profitabilitas. Artinya setiap peningkatan atau penurunan komposisi dewan direksi akan meningkatkan profitabilitas. Variabel komposisi komite audit berpengaruh positif dan signifikan terhadap profitabilitas. Artinya Artinya setiap peningkatan atau penurunan dewan komisaris berpengaruh signifikan terhadap profitabilitas. Variabel komposisi DPS tidak berpengaruh terhadap profitabilitas. Artinya setiap peningkatan atau penurunan DPS tidak berpengaruh signifikan terhadap profitabilitas.

\section{Daftar Pustaka}

Abdullah, Mal An. 2010. Corporate Governance Perbankan Syariah di Indonesia, (Jogjakarta: Ar-Ruzz Media)

Addiyah, Alina. 2014. Pengaruh Penerapan Corporate Governance Terhadap Kinerja Keuangan Perbankan (Studi Pada Perusahaan Perbankan yang Terdaftar di Bursa Efek Indonesia Tahun 2010-2012), Diponegoro Journal of Accounting, Vol.3 No.4

Adestian, Yuda. 2015. Pengaruh Dewan Komisaris, Dewan Komisaris Independen, Komite Audit, dan Ukuran Perusahaan Pada Kinerja Perusahaan Perbankan yang Listing di BEI Pada Tahun 2012-2014”. (Universitas Dian Nuswatoro)

Effendi, Arief. 2016. The Power of Good Corporate Governance Teori dan Implikasi (Jakarta: Salemba Empat)

Erfina, Erzi. 2014. Pengaruh GCG Terhadap Kinerja Keuangan Perbankan Syariah di Indonesia. (Publikasi Ilmiah Universitas Muhammadiyah Surakarta)

Febriani, Dini. 2016. Pengaruh Pengungkapan Islamic Social Reporting Terhadap Dana Pihak Ketiga Pada Bank Umum Syariah di Indonesia Periode Tahun 2010-201. (Skripsi Universitas Islam Bandung)

Kartika, Ika. 2014. Pengaruh Penerapan Good Corporate Governance Oleh Dewan Komisaris, Dewan Direksi, Komite-komite dan Dewan Pengawas Syariah Terhadap Kinerja Perbankan Pada Bank Umum Syariah di Indonesia Tahun 2010-2013. (Skiripsi UIN Syarif Hidayatullah Jakarta)

Laksmana, Yusak. 2009. Tanya Jawab Cara Mudah Mendapatkan Pembiayaan di Bank Syariah. (Jakarta: Gramedia) 
Maradita, Aldira. 2014. Karakteristik Good Corporate Governance Pada Bank Syariah dan Bank Konvensional (Vol.29 No.2 Mei-Agustus)

Muhammad. 2015. Manajemen Dana Bank Syariah. (Jakarta: Rajawali Pers)

Nalim. 2009. Good Corporate Governance Dalam Prespektf Islam.(Jurnal Hukum Islam IAIN Pekalongan)

Sholihin, Ifham Ahmad. 2010. Buku Pintar Ekonomi Syariah.(Jakarta: Gramedia Pustaka Utama)

Sriwedari, Tuti.2012. Mekanisme Good Corporate Governance Manajemen Laba dan Kinerja Keuangan Perusahaan Manufaktur di Bursa Efek Indonesia”. Jurnal Mediasi Vol.4 No.1

Sunarwan, Eko. 2015. Pengaruh Good Corporate Governance Terhadap Kinerja Keuangan Perbankan Syariah (Studi Kasus pada Bank Umum Syariah dan Unit Usaha Syariah di Indonesia Periode 2010-2013). Skripsi, (UIN Syarif Hidayatullah Jakarta)

Sutedi, Adrian. 2012. Good Corporate Governance (Jakarta:Sinar Grafika)

Usman, Rachmadi. 2012. Aspek Hukum Perbankan Syariah di Indonesia. (Jakarta: Sinar Grafika)

https://www.erhaje88.com/2018/03/meningkatkan-daya-saing-bank-syariah.html diakses pada tanggal 19 Maret 2018 pukul 10.36 WIB

https://www.syariahbank.com/perbedaan-bus-bank-umum-syariah-dan-uus-usahaunit-syariah/ diakses pada tanggal 19 Maret 2018 pukul 10.30 WIB

http://bisnisupdate.com/business-knowledge/read/icsa-pemerintah-punya-peranpenting-dalam-penerapan-gcg diakses pada tanggal 27 November 2017 pukul 09.54 WIB

http://www.beritasatu.com/ekonomi/431334-perppu-akses-keuangan-tak-ganggukinerja-bank.html diakses pada tanggal 19 Maret 2018 pukul 21.00 WIB http://investasi.kontan.co.id/news/gcg-menjadi-tanggung-jawab-ke-stakeholder diakses pada tanggal 19 Maret 2018 pukul 21.00 WIB 